\title{
Contribution of the Multidisciplinary Approach to Open Bite in Patients
}

\author{
Luciana Thaís Rangel Souza, ${ }^{1}$ João Pedro Cotrim Maia, ${ }^{1}$ Lorena Gonçalves Cardoso, ${ }^{1}$ Marcos Oliveira Sampaio, ${ }^{1}$ Diego Assis Santos Mota, ${ }^{5}$ \\ Anne Maria Guimarães Lessa ${ }^{6}$ \\ ${ }^{1}$ School of Dentistry, Independent College of the Northeast (FAINOR), Vitória da Conquista, BA, Brazil \\ - Conflicts of interest: none declared.
}

\section{Dear Editor,}

$\mathrm{O}$ pen bite $(\mathrm{OB})$ can be defined as a negative vertical overlap between antagonistic teeth, which can affect both anterior and posterior regions. Even more rarely, it can affect the entire dental arch. This absence of vertical contact between the teeth of the upper and lower arch can be presented under different magnitudes, varying from patient to patient. ${ }^{1}$ The literature also defines Anterior Open Bite (AOB) as the lack of incisal contact of the anterior teeth when in a centric relationship. ${ }^{1,2}$

The poor positioning of the tongue, deleterious oral habits, breathing difficulties or incomplete irruption of the anterior teeth are, in most cases, factors that result in AOB. Thus, it is understood that $\mathrm{AOB}$ is the result of the interaction of several etiological factors, ${ }^{3}$ which makes it a complex pathological condition, with important peculiarities. Thus, its treatment becomes difficult to solve, requiring a certain experience from the dental surgeon, a lot of cooperation from the patient, and the involvement of professionals from other areas, such as the speech therapist.

The patient's lip sealing may be deficient, and very often it is found: oral breathing, pathological phonation, gingival inflammation, disproportion of facial thirds, open goniac angle, inclined mandibular plane, thin and elongated symphysis, long clinical crowns, occlusal plane increased. ${ }^{4}$

In a comprehensive way, considering the structures it affects, AOB can be classified into skeletal, dentoalveolar or dental. It is very common in the literature to report the prevalence of $\mathrm{AOB}$ in a primary dentition, however, it is also reported that half of the cases regress with age. The treatment varies according to the particularities presented, and ranges from habit control to orthodontic treatment, even requiring a surgical procedure. ${ }^{5}$

For orthodontics, the treatment differs according to the diagnosis of AOB. From the same perspective, the speech therapist professional establishes the appropriate therapeutic conduct, varying according to the aforementioned classification. Radiographic cephalometric analysis is an essential tool for the diagnosis of anomalies related to malocclusion, thus favoring a differential diagnosis between skeletal and dental open bites. ${ }^{6}$

Pediatric dentistry and orthodontics were the first dentistry specialties to interact with speech therapy. Later, others such as: orthognathic surgery, prosthesis and periodontics started to understand the role of musculature and functions as etiological factors, modifiers or aggravating problems that until then were strictly judged to be the competence of the dental surgeon. The need to establish multiprofessional teams, competent to entirely solve complex problems, has increased a lot, bringing very satisfactory results. However, in general, there is still some resistance in the professional environment relating to interaction and communication, since many still do not believe it is a beneficial partnership. ${ }^{7}$

Orthodontics brings a range of possibilities with proven efficiency in literature for the treatment of $\mathrm{AOB}$. The use of palatine gratings, extraoral appliances, use of mini-implants or titanium plates, bite blocks and intermaxillary elastics are examples of techniques used in these vertical occlusion dysplasias ${ }^{5,8}$ treatment. However, there are factors to be considered before any intervention, since the non-elimination of the causal factor implies in the vast majority of cases in the relapse or failure of treatment. After eliminating the possible etiological factors of mouth breathing, the absence of difficulties in the passage of air in the nasal cavity, speech therapy for the reeducation of nasal breathing is initiated through specific techniques for better positioning of the oral musculature. ${ }^{9}$

Besides the important role of the orthodontist, it is up to the speech therapist to evaluate, diagnose and treat disorders of language, voice and oral motor skills. ${ }^{710}$ Restoring the posture of the tongue, jaw and lips, orofacial muscle tone, rebalancing the functions of chewing and swallowing, in addition to speech and breathing, re-teaching the patient to breathe through the nose, avoiding problems with oral motor skills. However, it is not possible for the speech therapist to modify and automate the nasal breathing pattern in the presence of nasopharyngeal obstruction. Its performance starts when the Otorhinolaryngologist intervenes with clinical and/or 
surgical treatment, eliminating nasopharyngeal obstruction, ${ }^{11}$ thus emphasizing the need for a multidisciplinary monitoring in the treatment of malocclusions. ${ }^{\text {? }}$

The interaction between orthodontic and speech therapy should be performed, if possible, in the same physical space, aiming to ease communication between professionals, so that it is possible to standardize the records and contemplate the objectives more efficiently. ${ }^{9}$

Although AOB is a widely discussed topic in the scientific literature, it is worth emphasizing the importance of multidisciplinary treatment. In this context, the present study aims, through a clinical case report, to reaffirm the importance of a multidisciplinary treatment in patients with AOB.

\section{Clinical Case Report}

This report was approved by the Human Research Ethics Committee, in accordance with the current resolution for Human Research Ethics No. 466/12 of the National Health Council (Ministry of Health, DF) (CAAE: 25862819.8.0000.5578, No opinion: 3,799.989).

Female patient, 23 years old, sought dental care in a private practice in the city of Vitória da Conquista - BA, in search of orthodontic treatment, complaining that her dental aesthetics did not please her, as her teeth were very projected and her anterior teeth was without contact, and with a space between them. During the anamnesis, she reported previous orthodontic treatment, and it was noticed some habits, such as of mouth breathing, lingual interposition, poor positioning of the tongue during speech, in addition to atypical swallowing. In the medical history there was no relevant fact and the general health condition was good.

The patient was referred to the otorhinolaryngologist for the soft tissues analysis of the oropharynx and nasal cavity, in order to rule out the possibility of alterations in the tonsils and adenoids. Then, she was referred to the speech language pathologist, along with orthodontic treatment, to eliminate the lingual interposition habit and to start the reeducation of tongue movements and nasal breathing.

In the extra-oral clinical examination, a straight profile, mesocephalic facial type and proportional facial thirds were verified. In the intraoral clinical examination, a $2 \mathrm{~mm}$ negative overbite and a normal overjet were noted (Figure 1). Angle Class III, canine ratio in Class III and lower midline deviated $2 \mathrm{~mm}$ to the left (Figure 2 ) were verified. In the initial cephalometric analysis, skeletal class I can be observed. Regarding the dental pattern, it was verified that the upper incisors were buccal and the lower incisors were slightly buccal (Figure 3 and Tables 1-2).

The first treatment started at 12 years of age. In the extraoral clinical examination, a straight profile and proportional facial thirds were verified (Figure 1). In the intraoral clinical examination, a large anterior open bite, Class I Angle, ectopic canines and a lower midline deviated to the left were observed (Figure 2). During orthodontic treatment, there was no record of interdisciplinary treatment.

In this study, we opted to install the complete upper fixed dental braces (Roth Ceramic Bracket - with Canine Hooks and Premolars 0.022"x 0.028" slot), including the second molars, with Roth prescription brackets (pre to premolar), Edgewise bracket in the first molars and simple tubes for bonding Roth 0.022" in the second molars (MORELLI Sorocaba - SP).
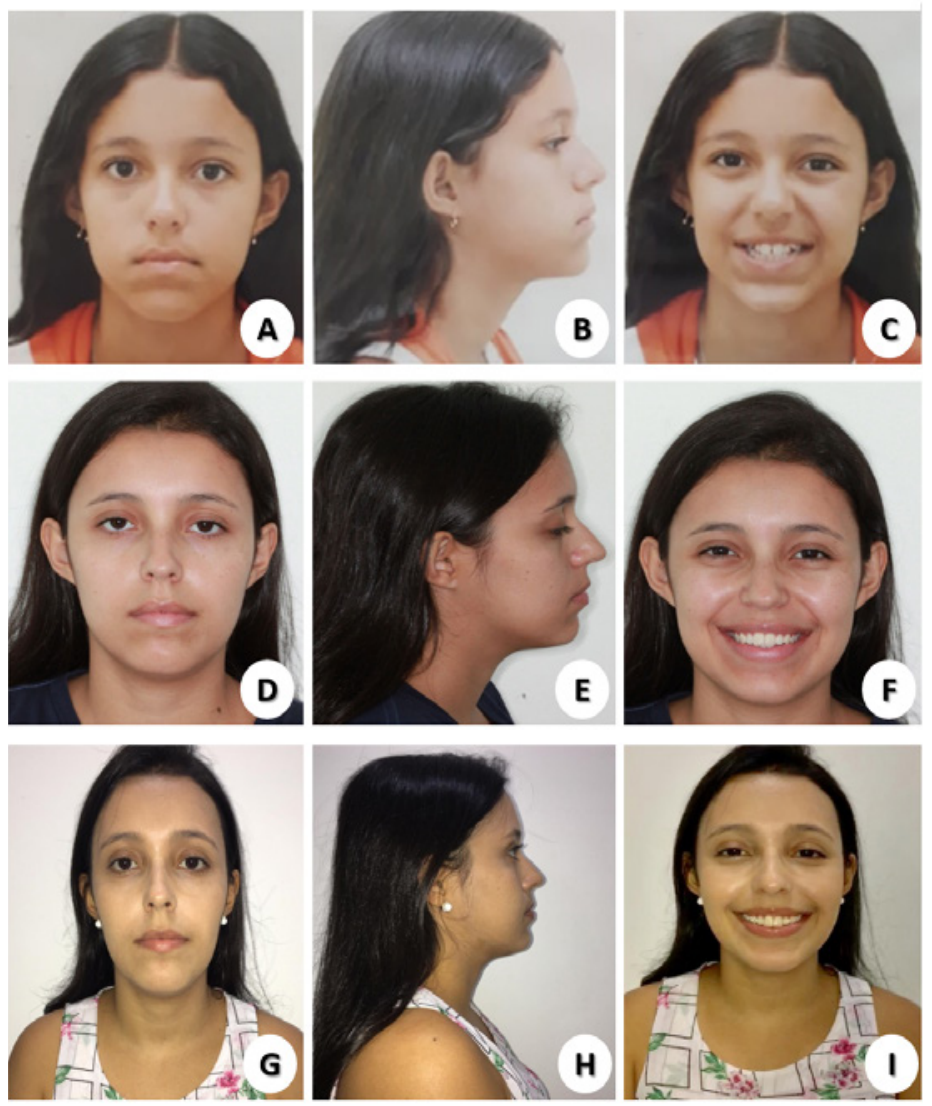

Figure 1. A, B and C - Initial extraoral photographs of the first treatment. $D, E$ and $F$ - Initial extraoral photographs before to retreatment.G, $\mathrm{H}$ and I - Extraoral photographs 06 months after retreatment.
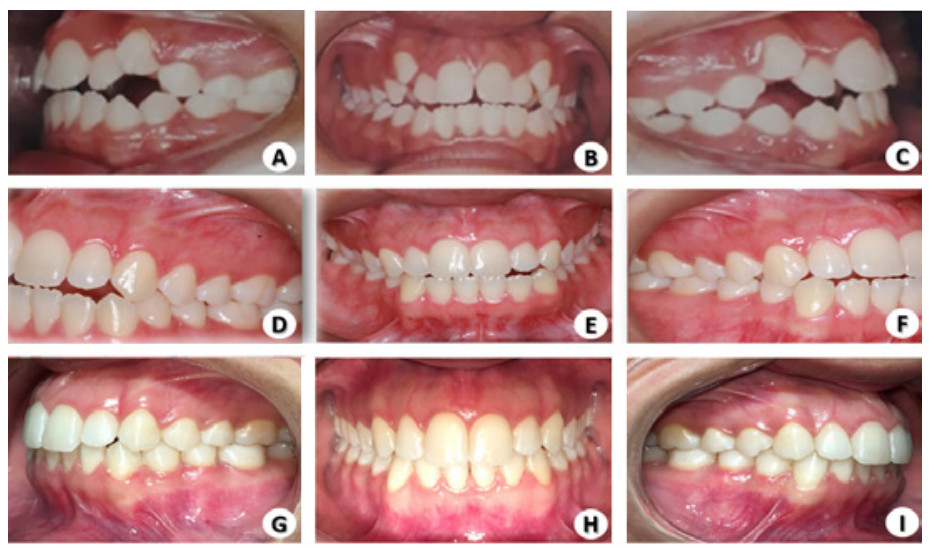

Figure 2. A, B and C - Initial intraoral photographs of the first treatment $D, E$ and $F$ - Initial intraoral photographs before to retreatment. G, H and I - Intraoral photographs 06 months after retreatment. 


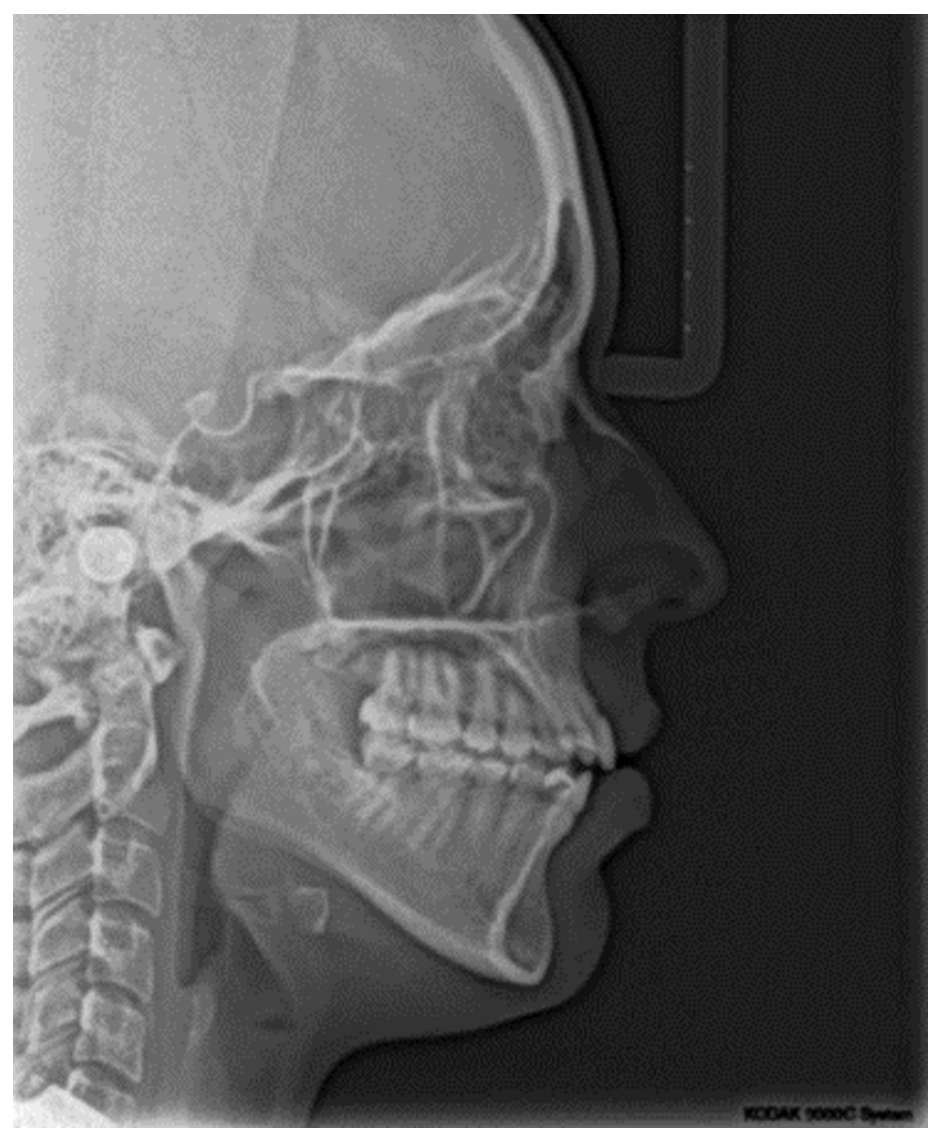

Figure 3. Teleradiography before to retreatment.

Table 1. Tweed Analysis in Orthodontics (Tweed's analysis)

\begin{tabular}{l|c|c}
\hline \multicolumn{1}{c|}{ Tweed's Analysis } & Standard & Clinical Case \\
\hline $\begin{array}{l}\text { Frankfurt Mandibular Plane } \\
\text { Angle (FMA) }\end{array}$ & $25^{\circ}$ & $28^{\circ}$ \\
\hline $\begin{array}{l}\text { Frankfurt Mandibular Incisal } \\
\text { Angle (FMIA) }\end{array}$ & $65^{\circ}$ & $64^{\circ}$ \\
\hline $\begin{array}{l}\text { Incisor Mandibule Plane } \\
\text { Angle (IMPA) }\end{array}$ & $90^{\circ}$ & $88^{\circ}$ \\
\hline
\end{tabular}

Concomitant to the start of treatment, the patient was referred to the otorhinolaryngologist and the speech therapist for monitoring and diagnosis of possible soft tissue changes. After the physiological alterations of the tongue, tonsils and adenoids were removed by the otorhinolaryngologist, the speech language pathologist identified changes in the improper positioning of the tongue during speech (horizontal posture of the tongue at rest), in addition to atypical swallowing and breathing.

The patient underwent 10 sessions of postural tongue reeducation and myofunctional therapy (MT), associated with awareness methods to seal the lip during sleep. The sessions took place once a week, for thirty minutes, aiming to reduce the sagging of the lower and upper orbicular muscles, buccinators and lingual muscles. Preparatory swallowing
Table 2. Steiner Cephalometric Analysis

\begin{tabular}{|c|c|c|}
\hline Steiner's Analysis & Standard & Clinical Case \\
\hline $\begin{array}{l}\text { GoGn-SN (Go=gonion } \\
\text { Gn=gnathion (mandibular plane)- } \\
\text { sella-nasion line }\end{array}$ & $32^{\circ}$ & $41^{\circ}$ \\
\hline SNA (sella-nasion-A point angle) & $82^{\circ}$ & $79^{\circ}$ \\
\hline SNB (sella-nasion-B point angle) & $80^{\circ}$ & $76^{\circ}$ \\
\hline $\begin{array}{l}\text { ANB (A point-nasion-B point } \\
\text { angle) }\end{array}$ & $2^{\circ}$ & $3^{\circ}$ \\
\hline SND (Sella-Nasion-Point D angle) & $76^{\circ}$ & $75^{\circ}$ \\
\hline $\begin{array}{l}\text { Ocl-SN (occlusal plane-sella-nasion } \\
\text { line) }\end{array}$ & $14^{\circ}$ & $20^{\circ}$ \\
\hline $\begin{array}{l}\text { 1-NA (Distance from the most } \\
\text { anterior part of the upper incisors } \\
\text { to the SN line) }\end{array}$ & $22 \%$ & $30 \%$ \\
\hline $\begin{array}{l}\text { 1-NB (Distance from the most } \\
\text { anterior part of the lower incisors } \\
\text { to the SN line) }\end{array}$ & $25 \%$ & $27 \%$ \\
\hline $\begin{array}{l}1-1 \text { (angle formed by the } \\
\text { intersection of the long axes of the } \\
\text { upper and lower incisors) }\end{array}$ & $131^{\circ}$ & $123^{\circ}$ \\
\hline $\begin{array}{l}\text { S-LS (distance between the most } \\
\text { prominent point of the upper lip } \\
\text { and Steiner's S line) }\end{array}$ & $0 \mathrm{~mm}$ & $0 \mathrm{~mm}$ \\
\hline $\begin{array}{l}\text { S-LI (distance between the most } \\
\text { prominent point of the lower lip } \\
\text { and Steiner's S line) }\end{array}$ & $0 \mathrm{~mm}$ & $2 \mathrm{~mm}$ \\
\hline
\end{tabular}

exercises were performed with the tongue snapped on the palate, as well as swallowing exercises of liquids and solid foods. Subsequently, the consultations were spaced out as the lingual positioning became more conscious.

The orthodontic treatment occurred concurrently with the aforementioned treatment, and consisted of alignment and leveling, evolving with the mechanics of light nickeltitanium (NiTi) and steel wires, nickel titanium alloys with copper (CuNiTi) to the heavier rectangular steel and then, the mechanics of intermaxillary elastics (1/8 heavy latex) were started for final intercuspation, indicated for 24 hours/ day, being removed only during meals and changed daily (Figure 4). After the end of the speech therapy treatment, the number of hours of elastics use was gradually reduced until their interruption and removal of the dental braces.

After the dental braces removal, 06 months of periodic observation of the case were carried out, in which it was possible to observe that the patient's occlusion became adequate, with good interincisal relationship, correct occlusal intercuspation, satisfactory protrusion and satisfactory protrusion and well-executed laterality movements (Figures 1 and 2). 

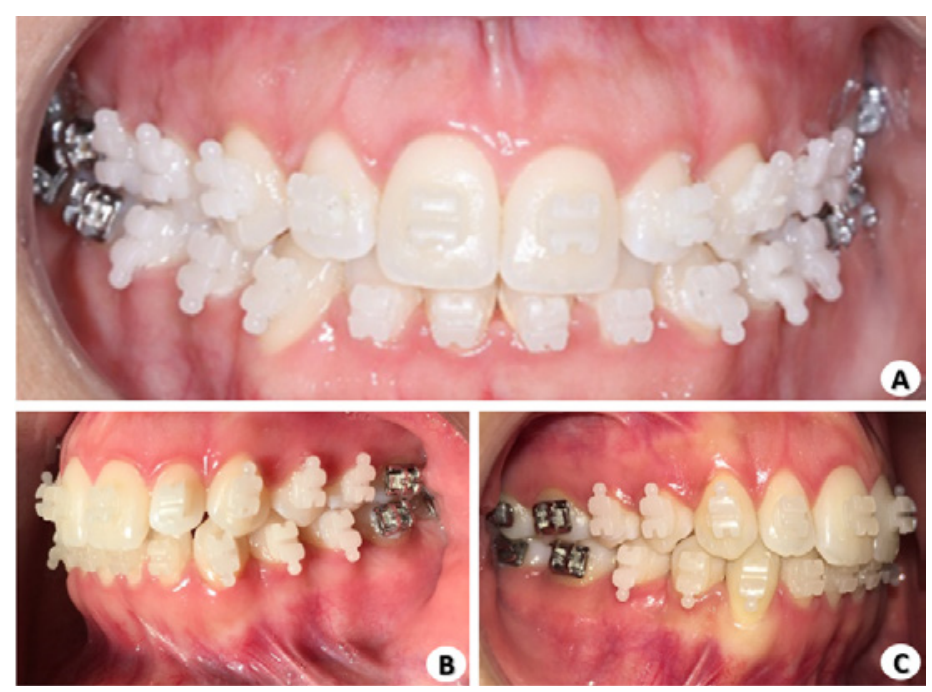

Figure 4. Period of completion of treatment after alignment and leveling and use of intermaxillary elastics. A - Left side view, B - Front view and C - Right side view

\section{Discussion}

Interdisciplinarity between the health areas has become necessary nowadays, with the objective of improving the $\mathrm{AOB}$ diagnosis and treatment, aiming at greater safety and confidence of the patients in the treatment's stability. In this sense, the balance reestablishment of the orofacial muscles, as well as respiratory problems and bucopharyngeal obstruction, must be observed by orthodontists, so that there is adequate referral.

Studies point out ${ }^{6,13}$ that the presence of harmful habits such as the occurrence of lingual interposition and atypical swallowing must be identified even before the beginning of orthodontic treatment. In the addressed clinical case, when starting the patient's anamnesis, it was observed that one of the main factors that led to the recurrence of $A O B$, was probably the poor posture of the tongue, also resulting in the dentalization of the phonemes / t /, / d /, / s /, / z /, / $1,{ }^{13}$ in addition to generating instability after the previous orthodontic treatment completion.

The importance of correcting the lingual interposition for the stability of the AOB treatment does not depend on the type of the orthodontic treatment chosen for the case. The removal of the harmful habit, associated with postural reeducation of the tongue and the $\mathrm{MT},{ }^{14}$ conceived adequacy of the structures during rest, adequacy of the lips positioning (in sealing) and adequacy of the tongue positioning (in the incisal papilla region), which was found previously disabled.

Due to the innumerable etiological factors described in the literature, $, 2,5,15,16$ an interdisciplinary evaluation of the patient was necessary, due to the different types of treatment proposed for the correction of AOB. According to the characteristics and type of open bite involved in the case, it was possible to choose the most appropriate treatment, which would include 10 sessions of tongue postural reeducation, associated with awareness methods with accessories to seal the lip during sleep. Orthodontic intervention was performed using intermaxillary elastics 24 hours a day, being removed only during meals and changed daily, which provided satisfactory results in the correction of intra-arch relations. ${ }^{10}$

According to studies, the clinical applicability of rubber bands must be well planned according to the intended result, always based on scientific evidence, considering their indications and limitations..$^{10}$ According to some authors, ${ }^{15,16}$ treatments can vary, ranging from the use of a simple palatal grid, to behavior modification to eliminate abnormal habits or functions, extrusion of anterior teeth or molar intrusion, surgical treatment of bone bases, appliances fixed and use of intermaxillary elastics, which were some of the treatment options for the resolution of the case.

When analyzing the teleradiography and cephalometric analyses, we noticed that the patient does not have excessive posterior dentoalveolar height, or at least exaggerated time rotation of the jaw, leading to admit that she did not demand treatments such as bite-blocks, multiloop edgewise archwire (MEAW) and mini-implants for molar intrusion. ${ }^{17}$ Therefore, the simplest treatment option would be with intermaxillary elastics, since there was no need for intrusion of the posterior teeth, but the patient's collaboration would be essential.

The gradual decrease in the hours number of intermaxillary elastics use occurred after discharge from speech therapy. ${ }^{9}$ It was only after the stability in the AOB's closing, provided by the postural tongue reeducation sessions, that they were suspended, and the dental braces were removed. The greatest difficulty regarding the correction of the $\mathrm{AOB}$ is the found results maintenance, that is, the stability of the adequate occlusion after the orthodontic treatment completion. Therefore, the best treatment option and/or mechanics for postural reeducation should be the least painful and traumatic possible for the patient, concomitantly with speech therapy, they still seem to be the best decision to minimize recurrences. Regardless of the chosen mechanics or treatment, whether by tooth extraction, molar intrusion with mini implants, use of intermaxillary elastics to extrude the anterior teeth, lingual spurs or even orthognathic surgeries, recurrences can happen. ${ }^{18}$

As a retainer, it was decided to use the Hawley plate with circumferential perforation in the incisive papillae region to continue the postural reeducation of the tongue. ${ }^{19}$ No other types of treatment were performed on this patient, but which can be seen 06 months after the completion of the treatment described in this case. The stability of the AOB correction is mainly due to the removal of its etiological factor and multidisciplinary monitoring. 


\section{Conclusion}

Given the addressed clinical case, it appears that $\mathrm{AOB}$ should be treated in a multidisciplinary approach. In orthodontics, the therapy for this condition is varied, with the use of intermaxillary elastics standing out, with good stability, function and aesthetics. After 06 months of periodic observation of the case, stability is still appropriate. Speech therapy monitoring was crucial to help maintain the case and prevent relapses, however long-term supervision is essential.

\section{References}

1. de Lima NS, de Melo Pinto E, Gondim PPC. Alterações Verticais na Dentadura Mista: Diagnóstico e Tratamento. J Bras Ort Ortop Facial. 2014; 7(42): 511-7.

2. de Almeida RR, de Almeida-Pedrin RR, de Almeida MR, Ferreira FPC, Pinzan A, Insabralde CMB. Displasias Verticais: Mordida Aberta Anterior - Tratamento e Estabilidade. Dental Press Ort Ortop Fac. 2003; 8(4):91 - 119.

3. de Almeida RR, Santos SCBN, Santos ECA, Insabralde CMB, Almeida MR. Mordida Aberta Anterior - Considerações e Apresentação de um Caso Clínico. Dental Press Ort Ortop Fac. 1998; 3(2):17 - 29.

4. Maciel CTV, Leite ICG. Aspectos etiológicos da mordida aberta anterior e suas implicações nas funções orofaciais. Pró-Fono Rev Atual Cient. 2005 12; 17(3):293 $-302$.

5. de Alencar Maia S, de Almeida MEC, da Costo AMM, Raveli DB, Dib LS. Diferentes abordagens no tratamento da mordida aberta anterior. ConScientia e Saúde. 2008; 1(7):77 - 82.

6. Alimere HC, Thomazinho A, de Felício CM. Mordida aberta anterior: uma fórmula para o diagnóstico diferencial. Pró-Fono Rev Atual Cient 2005; 17(3): 367-74.

7. Pereira CC, de Felício CM. Os distúrbios miofuncionais orofaciais na literatura odontológica: revisão crítica. Dental Press Ort Ortop Fac. 2005;10(4): 134-42. 8. Ramos AL, Zange SE, Terada HH, Hoshina FT. Miniplacas de ancoragem no tratamento da mordida aberta anterior. Dental Press Ort Ortop Fac. 2008 10; 13: 134-43.

9. Figueiredo RF, dos Santos BL, Aguiar NA, da Silva LM, Crepaldi MLS, Crepaldi AA. Relação interdisciplinar entre ortodontia e a fonoaudiologia. Rev FAIPE 2018; 8(1): 85- 100.

10. Loriato LB, Machado AW, Pacheco W. Considerações clínicas e biomecânicas de elásticos em ortodontia. Dental Press Ort Ortop Fac. 2006;5(1):42 - 55.
11. dos Santos Sousa RL, de Lima RB, Florêncio Filho C, de Lima KC, de Negreiros Diógenes AM. Prevalência e fatores de risco da mordida aberta anterior na dentadura decídua completa em pré-escolares na cidade de Natal/RN. Dental Press Ort Ortop Fac. 2017;12(2): 129-38.

12. Ianni Filho D, Bertolini MM, Lopes ML. Contribuição multidisciplinar no diagnóstico e no tratamento das obstruções da nasofaringe e da respiração bucal. Revista Clín de Ort Dental Press. 2005/2006;4(6):90 - 102.

13. Cavassani VG, Ribeiro SG, Nemr NK, Greco AM, Kohle J, Lehn CN. Hábitos orais de sucção: estudo piloto em população de baixa renda. Rev Bras Otorrinolaringologia. 2003; 69(1): 106-10.

14. Degan VV, Puppin-Rontani RM. Remoção de hábitos e terapia miofuncional: restabelecimento da deglutição e repouso lingual. Pró-Fono Revista de Atual Cient. 2005; 17(3): 375-82.

15. Saber M, de Jesus HB, Raitz R. Tratamento ortodôntico da mordida aberta anterior causada por hábitos deletérios. Rev Bras de Ciênc da Saúde. 2010; 25(8): 48-55.

16. Artese A, Drummond S, do Nascimento JM, Artese F. Critérios para o diagnóstico e tratamento estável da mordida aberta anterior. Dental Press J Orthod. 2011; 16(3): 136-61.

17. da Silva ANB, Valarelli FP, Paccini JVC, Rodrigues MTV, Cançado RH, de Freitas KMS. Intrusão de molares superiores para correção da mordida aberta anterior esquelética. Revista UNINGÁ. 2014; 41: 52-59.

18. Garrett J, Araujo E, Baker C. Open-bite treatment with vertical control and tongue reeducation. Am J Orthod Dentofacial Orthop. 2016; 149(2): 269-76. 19. Verri ACG, Lemos CAA, Cruz RS, Araújo CAM, Shibayama R, Verri FR Tratamento da mordida aberta anterior dentoalveolar e reeducação da postura lingual: relato de caso clínico. Arch Health Invest 2017; 6(9):423-30.

\section{Mini Curriculum and Author's Contribution}

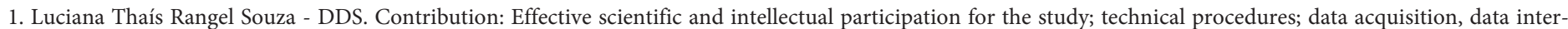
pretation; preparation and draft of the manuscript; critical review and final approval. ORCID: 0000-0001-6137-2228

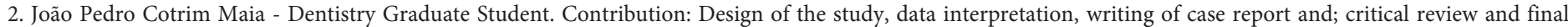
approval. ORCID: 0000-0002-2974-8800

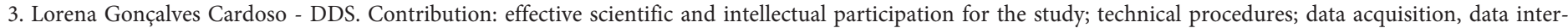
pretation; preparation and draft of the manuscript; critical review and final approval. ORCID: 0000-0001-6107-5776

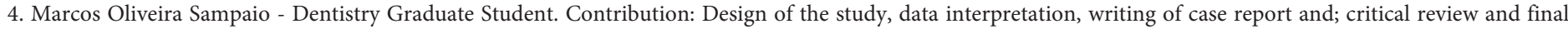
approval. ORCID: 0000-0002-3913-6090

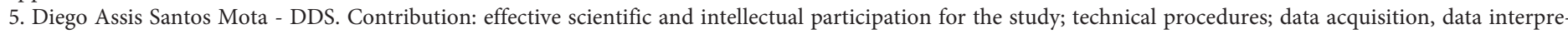
tation; preparation and draft of the manuscript; critical review and final approval. ORCID: 0000-0001-7548-823X

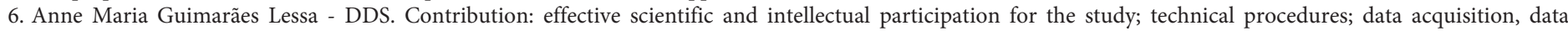
interpretation; preparation and draft of the manuscript; critical review and final approval. ORCID: 0000-0002-6477-9944

Submitted: 03/16/2020 / Accepted for publication: 03/30/2020

Corresponding author:

Anne Maria Guimarães Lessa

E-mail: anneglessa@gmail.com 